\title{
A child with end stage renal failure with acquired hepatitis $C$ infection who has undergone a successful renal transplant
}

\author{
*Randula Ranawaka1, T. Pathmanathan ${ }^{2}$, M P Gamage ${ }^{3}$, Asiri Abeyagunewardena ${ }^{4}$ \\ Sri Lanka Journal of Child Health, 2018; 47(4): 360-361 \\ DOI: http://dx.doi.org/10.4038/sljch.v47i4.8601 \\ (Key words: Hepatitis C infection, renal transplant, pegylated interferon, ribavirin)
}

\begin{abstract}
Introduction
Although blood donors are routinely screened for hepatitis $\mathrm{C}$ virus (HCV), HCV infection is still highly prevalent in haemodialysis (HD) patients and renal transplant recipients ${ }^{1}$. HCV-positive renal transplant patients have decreased graft survival in comparison with $\mathrm{HCV}$-negative renal transplant recipients $^{2}$. Following renal transplantation, immunosuppression significantly increases $\mathrm{HCV}$ viraemia ${ }^{3}$. Though $\mathrm{HCV}$ can often be eradicated using pegylated interferon (PEG-IFN) and ribavirin (RBV) in patients with normal renal function, their use in HD patients has been condoned only recently. PEG-IFN alfa was chosen because it is cleared predominantly via hepatic metabolism ${ }^{4}$. We report a successful eradication of hepatitis C (type 6 ) infection in a child with end stage renal failure (ESRF) on HD before renal transplantation.
\end{abstract}

\section{Case report}

A ten year old boy developed ESRF following posterior urethral valve. He was started on HD 3 years back and was found to have positive hepatitis $\mathrm{C}$ serology one year ago. At the start of HD he was negative for hepatitis $\mathrm{C}$ serology. Even though it is apparent that hepatitis $\mathrm{C}$ was transferred during $\mathrm{HD}$, the contact was not found. His hepatitis $\mathrm{C}$ (type 6) viral load polymerase chain reaction (PCR) increased with time and liver biopsy showed features of inflammation without any chronic damage.

\footnotetext{
${ }^{1}$ Consultant Paediatric Nephrologist, Department of Paediatrics, Faculty of Medicine, University of Colombo. ${ }^{2}$ Medical Officer, Teaching Hospital Peradeniya. ${ }^{3}$ Medical Officer, Lady Ridgeway Hospital for Children, Colombo, ${ }^{4}$ Professor in Paediatrics, Department of Paediatrics, Faculty of Medicine, University of Peradeniya

*Correspondence: rrandula@yahoo.com
}

(Received on 09 March 2017: Accepted after revision on 17 April 2017)

The authors declare that there are no conflicts of interest

Personal funding was used for the project.

Open Access Article published under the Creative

Commons Attribution CC-BY (c) (P)
He was listed for live related renal transplant and the prospective donor was his mother. He was started on combined therapy with PEG-INF and $\mathrm{RBV}$ in standard dosage regimen for one year. After 3 months following treatment the hepatitis $C$ PCR was negative. At 6 months hepatitis C PCR remained negative but his haemoglobin started to fall. His iron supplementation and erythropoietin was increased two fold and folic acid was added.

At around 9 months of treatment, he found difficulty in walking with weakness and nerve conduction studies revealed axonal degeneration consistent with peripheral neuropathy. Treatment with PEG-INF and RBV was stopped and he was started on regular physiotherapy. After 3 months he showed marked improvement in walking and hepatitis C PCR remained negative. At that point he had a live related renal transplant from his mother.

He had an uncomplicated post-operative period and was immunosuppressed with tacrolimus, mycophenolate mofetil (MMF) and prednisolone. His hepatitis C PCR was monitored at 3 monthly intervals for the first year and then at 6 monthly intervals. After 2 years of renal transplantation he remained negative for hepatitis C PCR with a properly functioning renal graft.

\section{Discussion}

Renal transplantation in a child with hepatitis $\mathrm{C}$ is a challenging goal. Chronic hepatitis $\mathrm{C}$ due to $\mathrm{HCV}$ genotype 6 is rare and is more often seen in Asians. Pegylated interferon plus ribavirin remains the treatment of choice for this genotype ${ }^{5}$. One study comprising 35 patients showed that haemodialysed chronic $\mathrm{HCV}$ patients awaiting renal transplant can be treated successfully with peginterferon alfa-2a (40 kDa) plus ribavirin ${ }^{6}$. All 35 patients achieved sustained virological response after 24 weeks of treatment-free follow-up ${ }^{6}$.

In our patient we used PEG-INF and RBV for 36 weeks before he developed peripheral neuropathy compared to previous study which used it for 24 weeks. Furthermore, we did not have the facility to monitor plasma concentration and the dose of ribavirin was not tailored according to haemoglobin 
level. Therefore, we assumed that the peripheral neuropathy occurred due to the longer duration of therapy or due to high plasm level of ribavirin.

Another study done on this aspect found that sustained virological response was achieved in $59 \%$ of patients with genotype 6 patients following 48 weeks of standard therapy ${ }^{7}$. In our patient we achieved sustained virological remission after 36 weeks of therapy and following two years after renal transplantation with immunosuppression he still remained Hep C PCR negative.

This case demonstrates that PEG INF and RBV are effective in treating Hep C genotype 6 infection and patients with Hepatitis $\mathrm{C}$ can undergo successful renal transplant following adequate treatment of the disease.

\section{References}

1. Bukh J, Wantzin P, Krogsgaard K, Knudsen F, Purcell RH, Miller RH et al. High prevalence of hepatitis $\mathrm{C}$ virus (HCV) RNA in dialysis patients: failure of commercially available antibody tests to identify a significant number of patients with HCV infection. Journal of Infectious Diseases 1993; 168:1343-8.

https://doi.org/10.1093/infdis/168.6.1343

PMid: 7504031

2. Morales JM, Campistol JM. Transplantation in the patient with hepatitis C. Journal of the American Society of Nephrology 2000; 11:1343-53. PMid: 10864593

3. Izopet J, Rostaing L, Sandres K, Cisterne $\mathrm{JM}$, Pasquier C, Rumeau JL et al. Longitudinal analysis of hepatitis $\mathrm{C}$ virus replication and liver fibrosis progression in renal transplant recipients. Journal of Infectious Diseases 2000; 181:852-8. https://doi.org/10.1086/315355

PMid: 10720504
4. Izopet J, Rostaing L, Moussion F, Alric L, Dubois M, That HT et al. High rate of hepatitis $\mathrm{C}$ virus clearance in haemodialysis patients after interferonalpha therapy. Journal of Infectious Diseases 1997; 176:1614-7.

https://doi.org/10.1086/517339

PMid: 9395376

5. Degos F, Pol S, Chaix ML, Laffitte V, Buffet $\mathrm{C}$, Bernard PH et al. The tolerance and efficacy of interferon-alpha in haemodialysis patients with $\mathrm{HCV}$ infection: A multicentre, prospective study. Nephrology, Dialysis, Transplantation 2001; 16:1017-23.

https://doi.org/10.1093/ndt/16.5.1017

6. Rendina M, Schena A, Castellaneta NM. The treatment of chronic hepatitis $\mathrm{C}$ with peginterferon alfa-2a $(40 \mathrm{kD})$ plus ribavirin in haemodialysed patients awaiting renal transplant. Journal of Hepatology 2007; 46:768-74.

https://doi.org/10.1016/j.jhep.2006.12.016 PMid: 17383045

7. Teta D, LandtwingL"uscher B, Gonvers J. Pegylated interferon for the treatment of hepatitis $\mathrm{C}$ virus in haemodialysis patients. Nephrology, Dialysis, Transplantation. 2005; 20:991-3.

https://doi.org/10.1093/ndt/gfh747

PMid: 15741205 